\title{
Implementasi Kearifan Lokal Masyarakat Kasepuhan Adat Sinar Resmi Dalam Pembentukan Karakter
}

\author{
Pudjiastuti, $\mathrm{SR}^{1 *}$, Sutarjo, $\mathrm{A}^{1}$, Nurhayati, $\mathrm{U}^{1}$ dan Fuadah, $\mathrm{VT}^{1}$ \\ ${ }^{1}$ Program, Magister PPKn STKIP Arrahmaniyah Depok, Indonesia
}

\begin{abstract}
Abstrak-Penelitian ini bertujuan untuk mendeskripsikan Implementasi Lokal Wisdom Masyarakat Kasepuhan Adat Sinar Resmi dalam Pembentukan Karakter, Tempat penelitian untuk mengambil objek kajian ini yaitu yang terletak di Desa Sinar Resmi Kecamatan Cisolok Kabupaten Sukabumi yang tergabung dalam Kasepuhan Adat Banten Kidul. Fokus penelitian ini terletak pada lokal wisdom, masyarakat Adat pembentukan karakter, dengan menggunakan kajian deskriptif kualitatif. Penelitian ini menggunakan metode observasi serta wawancara dengan Ketua Adat Kasepuhan Sinar Resmi Abah Asep Nugraha, sehingga pemeriksaan dengan cara observasi dan wawancara dapat ditemukan langsung peneliti lewat partisipasi aktif. Teknik pengumpulan data yang digunakan adalah observasi, wawancara, dan dokumentasi. dan penarikan kesimpulan. Tedapat Tiga komponen Lokal wisdom yang membentuk karakter Masyarakat Kasepuhan Adat Sinar Resmi, yaitu sistem politik (sistem kepengurusan adat), dan sistem kepercayaan, serta sistem Ritual (upacara menghargai leluhur). Yang berjalan dari generasi satu
\end{abstract} ke generasi selanjutnya hingga sekarang ini.

\author{
Kata kunci: \\ Kearifan lokal, \\ Masayarakat Kasepuhan, \\ Pembentukan karakter
}

Histori:

Dikirim: 19 Juli 2021

Direvisi: 20 Agustus 2021

Diterima: 13 September 2021

Online: 30 September 2021

\section{Identitas Artikel:}

Pudjiastuti, S.R, Sutarjo, A, Nurhayati, U \& Fuadah V.T. (2021). Implementasi Kearifan Lokal Masyarakat Kasepuhan Adat Sinar Resmi Dalam Pembentukan Karakter. Jurnal Citizenship Virtues, 1(2), 174-184.

\section{PENDAHULUAN}

Bangsa Indonesia merupakan bangsa yang majemuk. Masyarakatnya terdiri dari berbagai macam suku bangsa yang tersebar di seluruh kawasan nusantara. Setiap suku di setiap daerah memiliki adat dan budaya yang dikembangkan secara turuntemurun. Proses belajar kebudayaan akan menghasilkan corak kebuadayaan yang berbeda dan khas sehingga dapat dibedakan antara satu kebudayaan dengan kebudayaan lainnya. Manusia selalu belajar hal-hal baru agar mendapatkan pengetahuan yang baru atau memperoleh aturan-aturan dalam bertingkah laku yang baru. Hal ini bisa menyebabkan kebuadayaan dan adat yang baru, sebagaimana diungkapkan oleh Selo Soemarjan yang dikutip oleh Suwandi (2009) bahwa adanya perubahan social budaya pada umumnya disebabkan oleh pemikiran masyarakat yang beranggapan bahwa unsur-unsur yang diubah sudah

\footnotetext{
${ }^{1}$ *Corresponding author.

E-mail: yayu.pudjiastuti@gmail.com
} 
tidak memuaskan lagi dan ada factor baru yang lebih memuaskan bagi masyarakat tersebut. Selanjutnya Suwandi (2009) menjelaskan bahwa perubahan adat atau kebudayaan adalah perubahan yang terjadi dalam system ide yang dimiliki bersama oleh masyarakat yang bersangkutan antara lain mencakup aturan-aturan, norma-norma yang berlaku, nilai-nilai, teknologi dan keindahan/kesenian serta Bahasa.

Fenomena seperti ini biasanya terdapat pada lingkungan masyarakat tradisional yang taat mempertahankan warisan adat leluhurnya. Adanya sebuah kontra terhadap pengaruh luar, bukan berarti mereka mengasingkan diri dan tertutup dari pengaruh luar, akan tetapi dalam diri mereka adanya sebuah kekhawatiran apabila mereka menerima pengaruh dari luar system nilai yang dipertahankan akan mengalami perubahan dan pada titik puncaknya mengakibatkan terkikisnya adat atau kebudayaan mereka. Adat atau kebudayaan masyarakat tradisional atau yang dikenal dengan tradisi, biasanya diwariskan secara turun-temurun dari para leluhurnya. Perubahan tradisi baik secara kuantitatif yakni terkait para pengikutnya ataupun secara kualitatif yaitu kadar tradisi itu sendiri, terjadi karena interaksi kebudayaan itu sendiri. Apabila tradisi suatu masyarakat tersebut lebih kuat dari pengaruh luar maka akan terjadi akulturasi kebudayaan, tetapi apabila keduanya sama-sama kuat maka akan menghasilkan campuran kebudayaan.(Piotr;2019)

Kemajemukan lokal wisdom yang dimiliki setiap suku pada dasarnya merupakan aset kekayaan bangsa Indonesia. Berdasarkan realitas, kekayaan Lokal Wisdom yang dimiliki oleh bangsa Indonesia ternyata masih banyak yang belum dikembangkan dengan baik dan proporsional. Arti yang dimaksud adalah lokal wisdom belum dapat sepenuhnya menyentuh aspek kehidupan masyarakat sebagai media penumbuhan jati diri bangsa dan sebagai sumber potensi diri. Keragaman lokal wisdom sejatinya dapat dijadikan modal untuk memperkuat identitas kebangsaan, dan dapat dijadikan komoditas nasional yang bisa memberikan kontribusi bagi kesejahteraan masyarakat itu sendiri. Salah satu di antaranya Masayarakat Adat itu, ada masyarakat Adat Kasepuhan Sinar Resmi, yang terletak di Desa Sinar Resmi Kecamatan Cisolok Kabupaten Sukabumi dengan pemimpin adatnya Abah Asep Nugraha, merupakan salah satu masyarakat Adat yang tergabung dalam Kasepuhan Adat Banten Kidul yang terletak di kawasan Taman Nasional Gunung Halimun Salak (TNGHS), Jawa Barat.(Latifah;2008). Masyarakat adat kasepuhan Sinar Resmi tetap mempertahankan kearifan lokalnya (lokal wisdom) sebagai implementasi lokal wisdom yang membentuk karakter (perilaku) masyarakatnya sebagai pandangan hidup, mata pencaharian dan aktivitas lokal wisdom lainya yang berjalan dari generasi satu ke generasi selanjutnya hingga saat ini. Selain itu mereka juga berprinsip bahwa menjaga kelestarian alam, tidak hanya didorong oleh kesadaran bahwa bencana akan datang jika alam tak dijaga.(Pudjiastuti;2021)

Tujuan dari penelitian ini adalah: 1). Mengidentifikasi implentasi lokal wisdom pada masyarakat Kasepuhan Sinar Resmi; 2). Mengidentifikasi Karakter Masyarakat Kasepuhan Sinar Resmi didalam kehidupan sehari-hari. Hasil dari penelitian ini diharapkan dapat memberikan manfaat berupa: 1) Pemahaman implementasi lokal wisdom serta karakter masyarakat adat Kasepuhan Sinar Resmi sebagai dasar masyarakat, 2) Sebagai pertimbangan dalam penentuan kebijakan yang berkaitan dengan masyarakat adat. 


\section{METODE PENELITIAN}

Penelitian ini menggunakan pendekatan metodologi kualitatif, yang disajikan dalam uraian yang bersifat deskriptif. Pudjiastuti (2019) menjelaskan bahwa penelitian kualitatif merupakan penelitian yang digunakan untuk menyelidiki, menemukan, menggambarkan, dan menjelaskan kualitas atau keistimewaan. Kualitas atau keistimewaan yang dimaksud adalah kualitas dari lokal wisdom dalam pembentukan karakter masyarakat adat Kasepuhan Sinar Resmi, yang tidak dapat dijelaskan, diukur, atau Pada bagian analisis data-data dilakukan proses pelacakan dan pengaturan secara sistematis dimulai dari transkrip wawancara, catatan lapangan dan bahan-bahan lain, sehingga dapat ditafsirkan dan disajikan secara sistematis.

\section{HASIL DAN PEMBAHASAN}

Yunus (2012) mengartikan kearifan local sebagai budaya yang dimiliki oleh masyarakat tertentu dan ditempat-tempat tertentu yang dianggap mampu bertahan dalam menghadapi arus globalisasi, karena kearifan local tersebut mengandung nilai-nilai yang dapat dijadikan sebagai sarana pembangunan karakter bangsa. Pengertian kearifan local juga dikemukakan oleh Suhartini(2009) yang menyatakan bahwa kearifan local merupakan suatu bentuk kearifan lingkungan yang ada dalam kehidupan bermasyarakat di suatu tempat atau daerah yang merujuk pada lokalitas dan komunitas tertentu. Fajarini (2014) mengartikan kearifan local sebagai pandangan hidup dan ilmu pengetahuan serta berbagai strategi kehidupan yang berwujud aktivitas yang dilakukan oleh masyarakat local dalam menjawab berbagai masalah dalam pemenuhan kebutuhan mereka. Negara(2011) menyatakan bahwa kearifan local bukan hanya menyangkut pengetahuan atau pemahaman masyarakat adat/local tentang manusia dan bagaimana relasi yang baik diantara manusia, melainkan juga menyangkut pengetahuan, pemahaman, dan adat kebiasaan tetang manusia, alam, dan bagaimana relasi diantara semua, dimana seluruh pengetahuan itu dihayati, dipraktikkan, diajarkan, dan diwariskan dari satu generasi ke generasi. Permana (2010) menyebutkan adanya keterkaitan antara kearifan lokal dengan masyarakat lokal, dan dalam bahasa asing disebut sebagai lokal wisdom (kebijakan setempat), local knowledge (pengetahuan setempat), atau local genius (kecerdasan setempat). Pandangan hidup, pengetahuan serta berbagai strategi kehidupan yang berwujud aktivitas yang dilakukan oleh masyarakat lokal dalam menjawab berbagai masalah dalam pemenuhan kebutuhan mereka, meliputi seluruh unsur kehidupan; agama, ilmu dan teknologi, organisasi sosial, bahasa dan komunikasi, serta kesenian merupakan wujud kearifan lokal. Masyarakatnya memiliki pemahaman, program, kegiatan, pelaksanaan terkait untuk mempertahankan, memperbaiki, dan mengembangkan unsur kebutuhan dan cara pemenuhannya, dengan memperhatikan sumber daya manusia dan sumber daya alam di sekitarnya. Masyarakat juga memiliki pengetahuan akan adanya peringatan bencana alam. Pengetahuan masyarakat akan adanya peringatan dini bencana alam akan menentukan kesiapsiagaan masyarakat terhadap dampak bencana alam di masa mendatang.(Pudjiastuti,SR.2019)

Lebih lanjut, Permana (2010) menyebutkan bahwa kearifan lokal memiliki enam dimensi, yaitu: 1). Dimensi pengetahuan lokal; 2). Dimensi nilai lokal; 3). 
Dimensi keterampilan lokal sebagai kemampuan bertahan hidup (survival). Keterampilan lokal biasanya hanya cukup dan mampu memenuhi kebutuhan keluarganya masing-masatau disebut dengan ekonomi subsistensi; 4). Dimensi sumberdaya lokal, penggunaannya sesuai dengan kebutuhan, tidak melakukan eksploitasi secara besar-besaran atau dikomersialkan. Terdapat pembagian wilayah seperti hutan, kebun, sumber air, lahan pertanian, dan permukiman, dan kepemilikan sumberdaya lokal bersifat kolektif. 5). Dimensi mekanisme pengambilan keputusan lokal. Setiap masyarakat pada dasarnya memiliki pemerintahan lokal sendiri atau disebut pemerintahan kesukuan; 6).(Ahman;2010). Dimensi solidaritas kelompok lokal. Suatu masyarakat umumnya dipersatukan oleh ikatan komunal, ikatan komunikasi untuk membentuk solidaritas lokal. Setiap masyarakat mempunyai media-media untuk mengikat warganya yang dapat dilakukan melalui ritual keagamaan atau acara dan upacara adat lainnya. Dalam kearifan lokal terwujud upaya pengelolaan dan konservasi sumberdaya alam dan lingkungan. Nurroh, S(2014) mengemukakan prinsip-prinsip pengelolaan dan konservasi sumberdaya alam secara tradisional meliputi: 1). Rasa hormat yang mendorong keselarasan hubungan manusia dengan alam sekitarnya. Masyarakat tradisional cenderung memandang dirinya sebagai bagian dari alam, 2). Rasa memiliki yang eksklusif bagi komunitas atas suatu kawasan atau jenis sumberdaya alam tertentu sebagai hak kepemilikan bersama (communal property resource), 3). Sistem pengetahuan masyarakat setempat memberikan kemampuan kepada masyarakat untuk memecahkan masalah dalam memanfaatkan sumberdaya alam yang terbatas, 4). Daya adaptasi dalam penggunaan teknologi sederhana yang tepat guna dan hemat energi sesuai dengan kondisi alam setempat, 5). Sistem alokasi dan penegakan aturan-aturan adat yang bisa mengamankan sumberdaya milik bersama dari penggunaan berlebihan, baik oleh masyarakat sendiri maupun oleh masyarakat luar (pendatang),6).(Nurroh;2014) Mekanisme pemerataan (distribusi) hasil panen atau sumber daya milik bersama yang dapat mencegah munculnya kesenjangan dalam masyarakat. Keteraturan sosial mencegah terjadinya pelanggaran terhadap aturan adat yang berlaku dalam masyarakat.

Bentuk-bentuk kearifan local yang ada dimasyarakat menurut Aulia dan Darma (2010) dapat berupa nilai, norma, kepercayaan dan aturan-aturan khusus. Bentuk yang bermacam-macam ini mengakibatkan fungsi kearifan local menjadi bermacam-macam pula. Fungsi kearifan local tersebut antara lain untuk: (1) konservasi dan pelestarian sumber daya alam; (2) mengembangkan sumber daya mansia; (3) pengembangan kebudayaan dan ilmu pengetahuan; serta (4) petunjuk tentang petuah, kepercayaan, sastra, dan pantangan. Berbagai definisi kearifan local di atas pada dasarnya memiliki konsep yang sama, dimana kearifan local diartikan sebagai kumpulan pengetahuan yang berupa nilai, norma, dan aturanaturan khusus yang berkembang, ditaati, dan dilaksanakan oleh masyarakat di suatu tempat dan diwariskan dari generasi ke generasi. Pengetahuan-pengetahuan tersebut bersifat local, dapat berbeda antara satu daerah dengan daerah yang lain, meskipun memiliki makna yang sama.

Istilah kasepuhan berarti sepuh dalam Bahasa Sunda berarti tua. Kasepuhan yaitu tempat tinggal para sesepuh (leluhur), hal ini menunjukkan model system kepemimpinan dari suatu komunitas yang berasaskan adat kebiasaan orang tua (leluhur.)(Toto;2008) Masayarakat kasepuhan ini masih 
berpegang teguh kepada adat istiadat warisan leluhurnya, namun dalam hal ini bukan berarti mereka tertutup terhadap kemajuan teknologi, tetapi ada tradisitradsisi tertentu yang masih mereka pertahankan. Masyarakat ini pada intinya melestarikan warisan tradisi leluhur baik yang berkaitan dengan cara bertani yang khas, seperti bersawah ataupun berladang (ngahuma) serta tradisi-tradisi lainnya yang masih dipertahankan. Walaupun demikian, sebagaimana sifat dari kebudayaan bahwa kebudayaan akan selalu berkembang dan berubah (dinamis). Dalam hal ini masyarakat kasepuhan adat Banten Kidul lambat laun akan mengalami perubahan-perubahan, baik dalam skala kecil maupun besar. Thamrin (2014) mendefinisikan masyarakat adat sebagai sebuah kesatuan hukum, kesatuan penguasa dan kesatuan lingkungan hidup berdasarkan hak bersama atas tanah dan air bagi semua warganya. Hal ini sejalan dengan pendapat dari Aliansi Masyarakat Adat Nusantara (AMAN) dalam draf RUU Pengakuan dan Perlindungan Masyarakat Adat, dengan menambahkan faktor asal-usul leluhur secara turun temurun pada wilayah geografis tertentu, serta memiliki sistem nilai, ideologi, ekonomi, politik, budaya, sosial dan wilayah sendiri. Masyarakat adat dapat disebut juga sebagai masyarakat tradisional, dengan mencirikan adanya: 1). Ikatan yang erat antara masyarakat dengan lingkungan, 2). Sikap hidup dan tingkah laku yang magis religius, 3). Adanya kehidupan gotong royong, 4). Memegang tradisi dengan kuat, 5). Menghormati para sesepuh, 6). Kepercayaan pada pimpinan lokal dan tradisional, 7). Organisasi kemasyarakatan yang relatif statis, dan 8). Nilai sosial yang tinggi.

Nilai-nilai yang merupakan perwujudan karakter suatu masyarakat adat dapat digali melalui proses pendidikan dengan melibatkan anggota keluarga dan seluruh anggota masyarakat. Karena pada hakikatnya, pendidikan merupakan tanggung jawab setiap anggota keluarga, masyarakat, bangsa, dan negara, dalam rangka pembentukan generasi baru untuk kelangsungan umat manusia yang lebih baik. (Fajarini,U; 2014). Ada tiga sifat penting dari pendidikan, yaitu; 1). Pendidikan mengandung nilai dan memberikan pertimbangan nilai; 2). Pendidikan diarahkan pada kehidupan dalam masyarakat; 3). pelaksanaan pendidikan dipengaruhi dan didukung oleh lingkungan masyarakat. Dari sifat ketiga ini, maka ini lahirlah istilah pendidikan berbasis kearifan lokal atau etnopedagogi. (Sukmadinata, 2007)

Lokasi Penelitian Kasepuhan Sinar Resmi merupakan bagian dari kesatuan masyarakat adat Kasepuhan Banten Kidul, memiliki lembaga dan hukum adat serta secara turun temurun berpindah pada rentang wilayah Bogor dan Banten Selatan. Secara administratif di Kecamatan Cisolok Provinsi Jawa Barat sebenarnya ada 3 kasepuhan adat yaitu Kasepuhan Cipta Mulya, Kasepuhan Cipta Gelar, dan Kasepuhan Sinar Resmi. Kondisi alam Kasepuhan Sinar Resmi yang berada di pegunungan menyebabkan kondisi cuaca pada musim kemarau sangat panas dan pada musim dingin semakin dingin. Untuk menuju lokasi dapat ditempuh dengan kendaraan bermotor, namun karena jalannya agak sempit maka bis ukuran besar tidak bisa masuk hingga lokasi. Biasanya masyarakat akan menyediakan mobil kecil atau ojek untuk meneruskan perjalanan menuju lokasi. Luas wilayah Kasepuhan Sinar Resmi adalah 10 ha untuk ladang dan 1,5 ha untuk pemukiman dan sawah. 


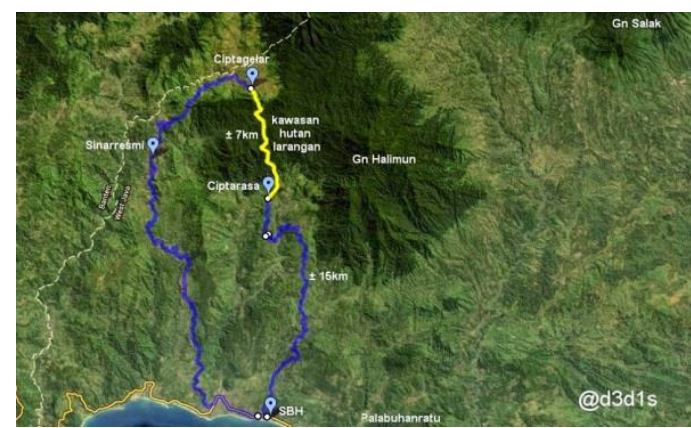

Gambar 1 : Lokasi Kasepuhan Sinar resmi

Kasepuhan Sinar Resmi merupakan salah satu kampung adat yang terletak di Kabupaten Sukabumi Jawa Barat. Kasepuhan Sinar Resmi dipimpin oleh Abah Asep yang berperan sebagai ketua adat masyarakat.

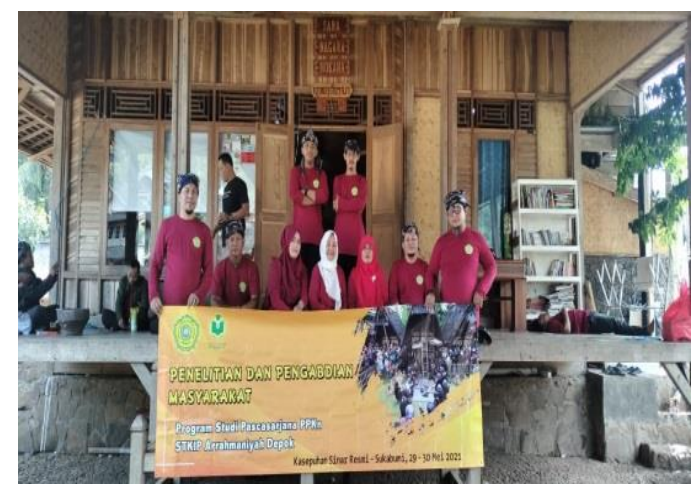

Gambar.2 Mahasiswa Pasca Sarjana PPKn di Sinar Resmi

Tempat ini menawarkan destinasi wisata budaya yang menarik, unik, penuh dengan nilai-nilai kearifan lokal, mistis, dan gaya hidup masyarakat yang bersatu dengan alam. Pesona alam yang masih asri dimana udaranya masih sejuk, air melimpah dan jernih, tumbuhan dan pepohonan hijau serta corak kehidupan masyarakat yang masih tradisional.

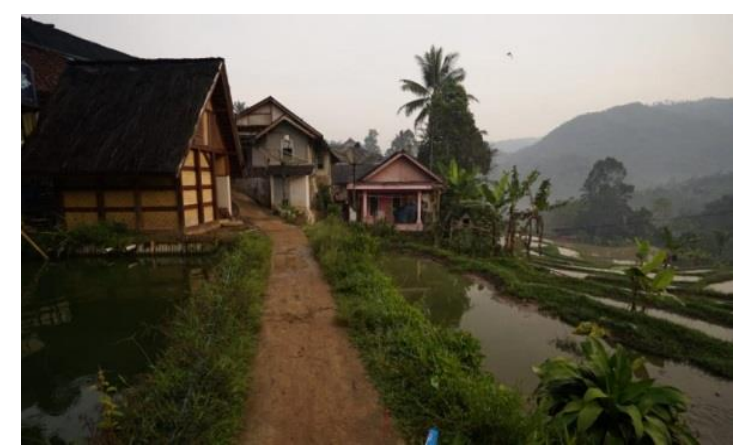

Gambar 3 : Kampung Kasepuhan sinar resmi

Kearifan lokal masyarakat Kasepuhan Sinar Resmi sangat tercermin dalam tata cara pertanian padinya. Para petani di sini masih memegang teguh warisan tradisi secara turun-temurun. Masyarakat setempat menganggap padi merupakan hal yang penting. Alih-alih hanya sekadar menjadi makanan pokok, padi juga dianggap sebagai bagian dalam tradisi budaya yang ada. Penanaman padi 
dilakukan setiap satu tahun sekali. Hal ini dilakukan dengan harapan dapat menjaga kelestarian tanah sawah agar dapat kesempatan untuk kembali mengumpulkan unsur hara sebanyak-banyaknya. Hal itu membuat semua warga kasepuhan ini tidak mengelola sawah secara individual atau masing-masing. Oleh karena itu, sektor pertanian di kawasan ini dikenal dengan sistem gotong royong.

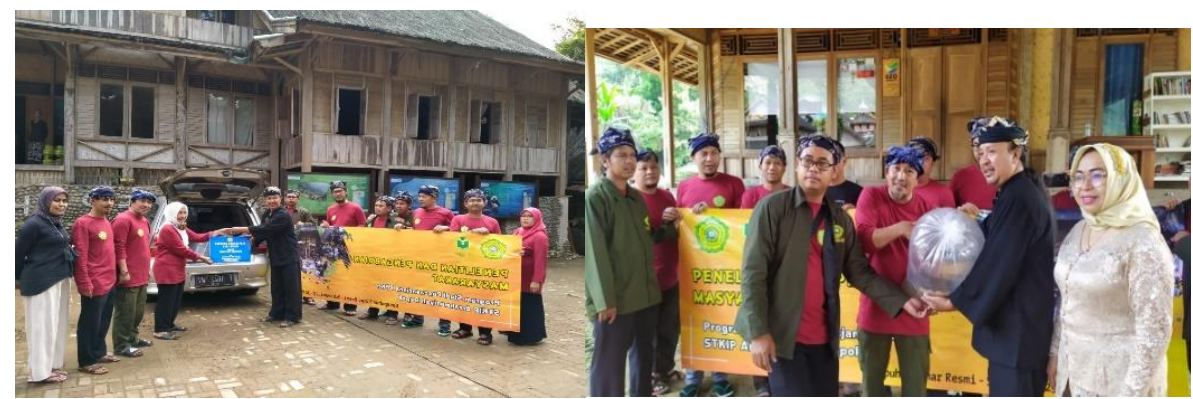

Gambar 3 : Bantuan Benih Ikan dari Mahasiswa Pasca Sarjana PPKn STKIP Arrahmaniyah Ke Abah Asep Nugraha

Selain itu, masyarakat di sini memiliki prinsip: tidak boleh mengurangi, kalau menambah silakan. Artinya, meskipun hidup dengan nilai-nilai kearifan yang masih terjaga, masyarakat adat juga tidak reaksioner terhadap kemungkinan untuk beradaptasi dengan hal-hal baru. Namun, apabila hal tersebut sekiranya dapat merusak maka masyarakat sudah pasti akan menolak. Hal tersebut dimaksudkan sebagai wujud konsistensi terhadap nilai-nilai yang menjadi pedoman hidup masyarakat setempat. Adalah Abah Asep Nugraha sebagai ketua adat ke-11 Kasepuhan Sinar Resmi yang memiliki peranan sentral dalam memelihara aturan dan kedaulatan adat, termasuk dalam kehidupan rakyat/pengikutnya dimana aktivitas ekonomi, sosial, serta mata pencahariannya bertumpu pada budidaya padi, dimana terdapat 68 varietas padi lokal yang masih ada di Kasepuhan Sinar Resmi. Beliau juga berperan dalam memelihara tradisi yang penuh dengan kearifan lokal yang membawa dampak nyata terhadap ketahanan pangan maupun lingkungan di Kasepuhan Sinar Resmi sehingga tidak pernah terjadi kerawanan pangan.

Atas konsistensi Abah Asep dalam menjaga adat dan tradisi ini, beliau telah dianugerahi penghargaan Adhikarya Pangan Nusantara kategori Pemangku Ketahanan Pangan pada tahun 2016 oleh Presiden RI, Joko Widodo. Dengan penghargaan ini, beliau berharap masa depan pertanian khususnya padi di wilayah Kasepuhan Sinar Resmi jelas identitas milik Kasepuhan dan ketersediaan lahan yang cukup untuk pengembangan budidaya dengan cara mendaftarkan varietas padi lokal yang dimiliki masyarakat Kasepuhan agar terjamin keaslian dan keamanannya serta dapat memberikan manfaat yang lebih luas lagi kepada masyarakat. 


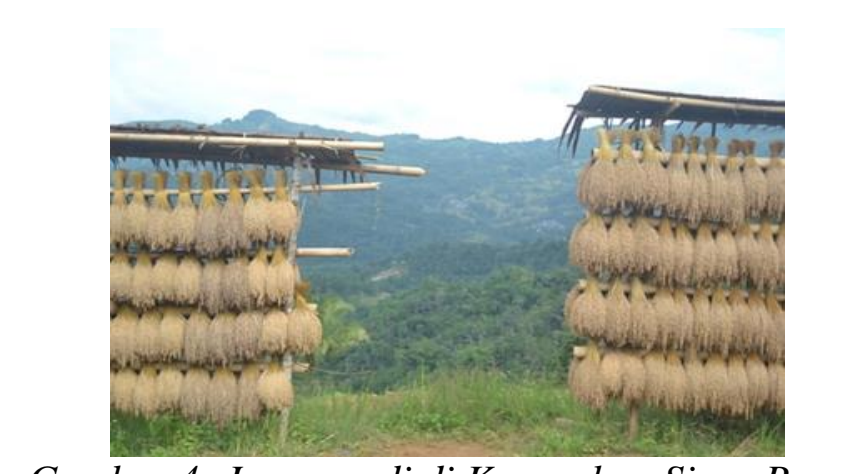

Filosofi hidup masyarakat Kasepuhan Sinar Resmi adalah sebagai Pancer pangawinan, yaitu mempersatukan manusa jeung kemanusaanna (manu- sia dengan kemanusiaannya), dan menjadi dasar dalam tindakan sehari-hari yang disebut ngaji diri (mawas diri) atau memahami diri sendiri. Bersikap mawas diri artinya selalu berhati-hati dalam bersi- kap dan berbicara terhadap sesama manusia. Ngaji diri menjadi pilar kehidupan masyarakat dalam membina hubungan antar sesama masyarakat kase- puhan, yakni dalam tekad, ucap jeung lampah (kemauan/ niat, perkataan dan perilaku). Niat merupakan titik awal dalam melakukan sesuatu yang tercermin da- lam perkataan dan perilaku seseorang, sehingga ketidaksesuaian antar ketiganya menimbul-kan perilaku munafik. Dalam berucap harus selalu sopan dan berhati-hati, 'saur kedah diukur, nyabda kedah diuger' agar tidak menimbulkan salah paham dan menyinggung perasaan orang lain. Masyarakat kasepuhan sangat bergantung pada sumberdaya alam di sekitarnya. Dalam istilah 'mipit kudu amit ngala kudu menta', masyarakat diwajibkan untuk memohon izin, yang diawali de- ngan doa untuk meminta keberkahan, keselamat- an dan keberhasilan saat memetik atau memanen tergantung pada sumberdaya alam di sekitarnya. Dalam istilah 'mipit kudu amit ngala kudu menta', masyarakat diwajibkan untuk memohon izin, yang diawali dengan doa untuk meminta keberkahan, keselamat- an dan keberhMasyarakat kasepuhan sangat beasilan saat memetik atau memanen di huma atau sawahnya. 'Ngereut jeung neundeun keur jaga ning isuk' bermakna menyisihkan untuk hari depan, sehingga akan berkecukupan di masa mendatang. Hal ini diwujudkan dalam bentuk leuit atau lumbung padi yang wajib dimiliki oelh setiap masyarakat kasepuhan. 'Saeutik, mahi loba nyesa halal didaharna' artinya sedikit ataupun cukup banyak hasil panen, harus menyisakan dan halal dimakan. Ungkapanungkapan tersebut mengandung makna bahwa masyarakat kasepuhan memiliki sikap hidup bersahaja dan sederhana, dengan pemuas kebu- tuhan yang terbatas harus dapat mencukupi ke- butuhan hidup, namun saat memiliki kelebihan materi harus menyisihkan serta mendapatkan sesuatu harus dengan cara yang halal.

Sosial-Budaya Kasepuhan Banten Kidul

Makna yang tersirat dari sebuah kasepuhan adalah adanya pelestarian dari nilai-nilai tradisi yang diwariskan oleh nenek moyang, dalam masya- rakat kasepuhan disebut sebagai tatali paranti karuhun. Sebuah kasepuhan dipimpin oleh tutunggul yang ditunjuk berdasarkan petunjuk gaib (wangsit) dari tutunggul 
sebelumnya. Ketua kasepuhan tidak boleh menjabat dalam struktur pemerintahan desa agar tidak terjadi kerancuan dalam melestarikan tatali paranti karuhun. Incu putu (keturunan) masya- rakat adat Kasepuhan Banten Kidul tersebar di berbagai wilayah di Sukabumi, Bogor, Lebak, Banten Selatan, Bandung, Jakarta, Cirebon, Kuningan maupun di beberapa kota di luar Jawa.

\section{KESIMPULAN}

Berdasarkan hasil temuan mengenai penelitian yang berjudul "Implementasi Lokal Wisdom Masyarakat Adat Kasepuhan Sinar Resmi Dalam Pembentukan Karakter" terdapat beberapa hal yang dapat disimpulkan oleh peneliti dapat disimpulan yaitu: Pertama, kondisi sosial budaya yang berlaku pada masyararakat adat Kasepuhan Sinar Resmi terbentuk berdasarkan nilai-nilai yang dianut dan diterapkanmasyarakatnya dalam kehidupan sehari-hari. Adapun karakteristik yang dimiliki masyarakat adat Kasepuhan Sinar Resmi sebagai masyarakat adat adalah nilai budaya pertanian yang masih dilestarikan. Sebagai masyarakat adat yangmemegang teguh tradisi pada Dewi Sri, maka proses penanaman padi menjadi sebuah tradisi sakral yang pada setiap tahapnya harus dibarengi dengan ritualritual adat. Selain itu, nilai gotong royong menjadi salah satu nilai sosial yang masih dikembangkan dan dilaksanakan hingga saat ini oleh masyarakat adat dalam bidang pertanian, pembangunan imah gede, serta fasilitas umum lainnya. Kentalnya nilai gotong royong yang berlaku pada masyarakat adat di Kasepuhan Sinar Resmi disebabkan sistem kekerabatan yang memiliki ikatan erat. Selain itu nilai gotong royong merupakan salah satu karakteristik yang dimiliki oleh masyarakat petani yang ada di perdesaan.

Kedua, tahap-tahap perubahan yang terjadi pada masyarakat adat Kasepuhan Sinar Resmi terbagi dalam tiga fase, yaitu fase terciptanya ide perubahan pada masyarakat adat terjadi pada periode 1959-1966 saat kasepuhan menempati Sirna Resmi dan dibawah pimpinan Abah Arjo sebagai tokoh yang mengawali untuk dilaksanakan sebuah perubahan, fase terjadinya adopsi terhadap perubahan berada di periode 1966-2002 saat masyarakat adat mulai menerima nilai-nilai baru dari lingkungan luar dan mulai ada perbaikan pembangunan yang dilakukan pemerintah, serta tahap akhir yang merupakan fase modernisasi terjadi pada periode 2002-2018 yang merupakan abad teknologi mulai masif memasuki perkampungan dan kasepuhan. Awal terbukanya sifat masyarakat adat Sinar Resmi terjadi pada tahun 1960 saat kasepuhan berada dalam kepemimpinan Abah Arjo yang mulai membuka interaksi dengan pemerintah dan masyarakat luar. Adanya keterbukaan tersebut semakin berlanjut terutama pada tahun 1966 saat terjadi peralihan kekuasaan dari Orde Lama ke Orde Baru. Peranan Abah Arjo sebagai seorang sesepuh girang yang secara tidak langsung juga bertindak sebagai agent of change, menandakan bahwa perubahan yang terjadi pada masyarakat adat merupakan bentuk perubahan yang dikehendaki dan mengisyaratkan bahwa masyarakat adat telah siap pada hal-hal baru yang akan diterimanya. Perubahanperubahan yang terjadi pada lingkungan masyarakat adat semakin masif terjadi pada akhir tahun 90-an dan awal tahun 2000-an dengan diperbaikinya akses infrastruktur jalan serta mulai dilakukan perbaikan pembangunan sarana pendidikan di wilayah Kasepuhan Sinar Resmi. Mulai adanya kesadaran masyarakat adat terhadap pendidikan yang berlangsung pada tahun 2005 
mengartikan bahwa telah ada perubahan pola pikir yang lebih maju pada masyarakat adat.

Ketiga, adapun faktor penyebab perubahan-perubahan yang terjadi pada masyarakat adat Kasepuhan Sinar Resmi didorong oleh faktor internal dan faktor eksternal yang ada di lingkungan masyarakatnya. Faktor pendorong internal berupa adanya keinginan masyarakat adat untuk lebih maju yang tercermin pada kesadaran terhadap pendidikan semakin meningkat, adanya sifat terbuka yang dimiliki oleh masyarakat adat terhadap kebudayaan-kebudayaan yang berasal dari luar, serta lapisan sosial yang terbuka. Sedangkan faktor eksternal berupa adanya pengaruh kebudayaan yang berasal dari luar lingkungan masyarakat adat, munculnya penggunaan alat-alat elektronik karena masuknya jaringan listrik ke wilayah kasepuhan, serta adanya perbaikan sarana pendidikan di lingkungan kasepuhan.

Keempat, adanya sifat terbuka masyarakat adat terhadap dunia luar menyebabkan masuknya pola hidup modern yang diterapkan dalam bentuk penggunaan teknologi dalam kehidupan sehari-harinya. Hal tersebut kemudian menyebabkan terkikisnya nilai-nilai sosial budaya pada generasi muda dalam cara berpakaian, berkomunikasi atau berinteraksi, dan perubahan pada beberapa bentuk rumah yang ada di wilayah Kasepuhan Sinar Resmi menjadi contoh dampak negatif terhadap modernisasi yang dilakukan oleh masyarakat adat. Untuk mengatasi hal tersebut, upaya pelestarian yang dilakukan masyarakat adat adalah diadakannya acara saresehan atau pemberian nasehat dan wejangan oleh sesepuh girang pada masyarakat. Sedangkan upaya yang dilakukan oleh pemerintah yaitu dilakukannya upaya promosi wisata ke Kasepuhan Sinar Resmi dalam bentuk brosur dan booklet, serta dukungan dalam bentuk bantuan dana pada setiap pelaksanaan acara-acara yang ada di Kasepuhan Sinar Resmi.

\section{REFERENSI}

Ahman, Kamil, M.Permana.J.(2010). Pendidikan Lingkungan Sosial Budaya dan Teknologi. UPIPRESS.

Aulia, TOS. AH.Dharmawan (2010), "Kearifan Lokal dalam Pengelolaan Sumber Daya Air di Kampung Kuta". Sodality: Jurnal Transdisiplin Sosiologi, Komunikasi, dan Ekologi Manusia. 4 (3): 345-355.

Fajarini,U.(2014) Peranan Kearifan Lokal Dalam Pendidikan Karakter. Sosiao Didaktika 1(2):123-130.

Latifah Hendarti, (2008). Menepis Kabut Halimun. Yayasan Obor Indonesia.

Negara,PD.(2011), "Rekonsruksi Kebijakan Pengelolaan Kawasan Konservasi

Berbasis Kearifan Lokal Sebagai Kontribusi Menuju Pengelolaan Sumber Daya Alam yang Indonesia". Jurnal Konstitusi. IV (2): 91-138.

Nurroh,S. (2014) Studi Kasus:Kearifan Lokal (Local Wisdom) Masyarakat suku sunda dalam pengelolaan lingkungan yang berkelanjutan. Pasca Sarjana Universitas Gajah Mada.

Piotr Sztompka. (2011). Sosiologi Perubahan Sosial. Prenada.

Pudjiastuti, SR, HS.Iriansyah, Y Yuliwati(2021), "Program Eco-Pesantren Sebagai Model Pendidikan Lingkungan Hidup". Jurnal Abdimas Prakasa Dakara 1(1). 29-37.

Pudjiastuti,SR. (2019) Penelitian Pendidikan. Media Akademi. 
Pudjiastuti, SR (2019), "Mengantisipasi dampak bencana alam", Jurnal Ilmu Pendidikan (JIP) STKIP Kusuma Negara. 10(2), 1-14.

Sukmadinata, Nana Syaodih, (2004), Landasan Psikologi Proses Pendidikan, Bandung PT Remaja Rosdakarya.

Suwandi Alamsyah,dkk, "Kasepuhan Sinar Resmi: Profil Komunitas Adat di Kabupaten Sukabumi”, Laporan Penelitian, Bandung: BPNB Bandung: 2009.

Suhartini,(2009). "Kajian Kearifan Lokal Masyarakat Dalam Pengelolaan Sumber

Daya Alam dan Lingkungan". Prosiding Seminar Nasional Penelitian Pendidikan dan Penerapan MIPA. Fakultas MIPA Universitas Negeri Yogyakarta yang diselenggarakan pada 16 Mei 2009.

Thamrin, Husni (2014), Revitalisasi Kearifan Lokal Melayu Dalam Menjaga Harmonisasi Lingkungan Hidup. Jurnal Toleransi:Media Komunikasi Umat Beragama. 6(1).

Toto Sucipto, dkk. "Upaya perlindungan Sosial Masyarakat Kasepuhan Ciptagelar di Kabupaten Sukabumi”. Laporan Penelitian, Bandung:Balai Pelestarian Sejarah dan Nilai Tradisional Bandung 2008.

Yunus, R.(2012), Nilai-Nilai Kearifan local (Lokal Genius) sebagai Penguat Karakter Bangsa: Studi Empiris Tentang Huyula. Budi Utama. 